Abstracta Iranica Abstracta Iranica

Revue bibliographique pour le domaine irano-aryen

Volume 27 | 2006

Comptes rendus des publications de 2004

\title{
«La 'Porte de la Vallée' et la limite occidentale de la Cité de David à Jérusalem : topographie et archéologie ». Transeuphratène, 28 (2004), pp. 33-39.
}

\section{Astrid Nunn}

\section{(2) OpenEdition}

Journals

Édition électronique

URL : http://journals.openedition.org/abstractairanica/5676

DOI : 10.4000/abstractairanica.5676

ISSN : 1961-960X

Éditeur :

CNRS (UMR 7528 Mondes iraniens et indiens), Éditions de l'IFRI

Édition imprimée

Date de publication : 15 mai 2006

ISSN : 0240-8910

Référence électronique

Astrid Nunn, « «La 'Porte de la Vallée' et la limite occidentale de la Cité de David à Jérusalem:

topographie et archéologie ». Transeuphratène, 28 (2004), pp. 33-39. », Abstracta Iranica [En ligne],

Volume 27 | 2006, document 58, mis en ligne le 02 janvier 2007, consulté le 25 septembre 2020. URL :

http://journals.openedition.org/abstractairanica/5676 ; DOI : https://doi.org/10.4000/

abstractairanica.5676

Ce document a été généré automatiquement le 25 septembre 2020.

Tous droits réservés 


\section{« La 'Porte de la Vallée' et la limite occidentale de la Cité de David à Jérusalem : topographie et archéologie ». Transeuphratène, 28 (2004), pp. 33-39.}

\section{Astrid Nunn}

L'étendue de Jérusalem à l'époque perse reste un sujet de débat. L'A. s'attache dans cet article aux structures massives fouillées dans les années 1920 dans la Vallée du Tyropoeon sur le flanc ouest de la Cité de David. Il s'y trouve une porte tôt identifiée comme la "porte de la Vallée». La porte pourrait remonter au Bronze ou au Fer et aurait été remaniée à l'époque achéménide. D'autre part de nombreux chercheurs penchent vers une datation hellénistique. Pour des raisons de construction, pour son emplacement et son plan qui peut être comparé à d'autres en Palestine, la porte remonte, d'après l'A, au Bronze, probablement au Bronze Moyen. Cette porte en outre n'est pas la «porte de la Vallée » restaurée par Néhémie. Cette partie de la ville était peut-être inoccupée à l'époque perse et le tracé de la muraille serait à rechercher ailleurs, plus haut sur la colline.

INDEX

Thèmes : 3.2.1. Elam 
AUTEURS

ASTRID NUNN

Université de Munich 